\title{
The association between BMI and gallbladder cancer risk: a meta-analysis
}

\author{
Zhan-Ming Li ${ }^{1,2}$, Zhao-Xia Wu' ${ }^{1}$, Bing Han ${ }^{1}$, Yu-Qin Mao ${ }^{2}$, Hui-Ling Chen ${ }^{1}$, San-Feng \\ Han ${ }^{1}$, Jing-Lin Xia ${ }^{1}$, Li-Shun Wang ${ }^{1}$ \\ ${ }^{1}$ Institute of Biomedical Sciences, Minhang Hospital, Fudan University, Shanghai, P.R. China \\ ${ }^{2}$ Ruijin Hospital, Shanghai Jiao-Tong University School of Medicine, Shanghai, P.R. China \\ Correspondence to: Li-Shun Wang, email: lishunwang@fudan.edu.cn \\ Jing-Lin Xia, email: xiajinglin@fudan.edu.cn \\ Keywords: BMl, gallbladder cancer, meta-analysis, overweight, obese \\ Received: October 22, $2015 \quad$ Accepted: May 11, $2016 \quad$ Published: May 27, 2016
}

\section{ABSTRACT}

Obesity is a known cause of gallstone formation and gallstones increases the risk of gallbladder cancer (GBC), but the relation of body mass index (BMI) to GBC remains incompletely understood. To help elucidate the role of obesity in GBC, we performed a meta-analysis of the relationship between BMI and GBC risk. PUBMED and EMBASE databases were searched up to April 17, 2016. Fifteen articles with 5902 cases were identified. Random-effects models and dose-response meta-analyses were used to pool study results. Compared to normal weight, the pooled relative risks (RRs) and the corresponding 95\% confidence intervals (CI) of GBC for overweight and obesity is $1.10(0.98-1.23)$ and $1.58(1.43-1.75)$ respectively. The RRs and $95 \%$ CI of overweight and obesity in man are $0.98(0.90-1.08)$ and $1.43(1.19-1.71)$, while the corresponding RRs in woman are $1.29(1.08-1.55)$ and $1.68(1.41-2.00)$ when compared to normal weight. A nonlinear dose-response relationship between $B M I$ and risk of $G B C$ was found $(P=0.001)$, and the risk increased by $4 \%$ for each $1 \mathrm{~kg} / \mathrm{m}^{2}$ increment in $B M I$. When adjusted for sex, at the point of $B M I=25 \mathrm{~kg} / \mathrm{m}^{2}$, the RRs (95\% CIs) for women and men were $1.13(1.01-1.25)$ and $0.98(0.90-1.07)$ respectively. The corresponding RRs ( $95 \% \mathrm{CIs})$ at the point of $\mathrm{BMI}=30 \mathrm{~kg} / \mathrm{m}^{2}$ were $1.56(1.39-1.75)$ vs. $1.24(1.06-1.44)$. These results suggest that association of obesity and risk of GBC is stronger in woman. Furthermore, overweight is only associated with GBC in woman. A even stricter weight control might be necessary for woman to prevent GBC.

\section{INTRODUCTION}

Gallbladder cancer (GBC) is the most common malignancy of the biliary tract, representing $80-95 \%$ of biliary tract cancers worldwide $[1,2]$. This tumor ranks fifth among gastrointestinal cancers and it is traditionally regarded as a highly lethal disease with an overall 5-year survival of less than 5\% [3]. The overall mean survival rate for patients with GBC is 6 months [4]. However, the causes for carcinogenesis of GBC are largely uncertain except the gallbladder stone [5].

The global prevalence of excess bodyweight in adults increased by $27.5 \%$ between 1980 and 2013, although the increase has slowed in recent years in some European countries and the USA [6-9], according to recent estimates $[10,11]$. This problem is of great concern for public health, as excess body weight is known to be a major risk factor for cardiovascular disease, type 2 diabetes and certain cancer types [12,13]. Overweight and obesity may also have an increased risk of developing GBC [14-16], but the relationship of body mass index (BMI) to GBC remains incompletely understood. For example, the sex difference for the risk of BMI on GBC had not been well elucidated. We therefore conduct a systematic meta-analysis to assess the associations of overweight and obesity with risk of GBC. 


\section{RESULTS}

\section{Literature search and study characteristics}

A total of 10 cohort studies [17-26] and 5 casecontrol studies [27-31] included in the meta-analysis and involved a total of 5902 cases (Figure 1). The duration of follow-up ranged from 4.8 to 23 years. Among these studies, $8[17,19,21,22,27-30]$ in white, $5[18,23-26]$ in Asian, and $2[20,31]$ in mixed population. 3 studies $[19,20,25]$ and 2 studies [26, 27] reported sole outcomes of males or females, respectively. 10 studies $[17,18,21-24,28-31]$ reported outcomes of both sex. Of the 10 studies, 7 [17, 18, 21-24, 31] reported outcomes of males and females separately while 3 studies [28-30] provided data of males and females combined. Main characteristics of the studies are shown in Table 1.

\section{Abnormal BMI and risk of GBC}

Compared to the reference category (normal weight), the combined RRs (95\% CIs) of GBC were $1.10(0.98-1.23)$ and $1.58(1.43-1.75)$ for the category of overweight and obesity, respectively (Figure 2 \& Figure 3). No evidence for high heterogeneity among studies was found in the analyses (overweight: $\mathrm{I}^{2}=31.6 \%$; obesity: $\mathrm{I}^{2}=1.9 \%$ ).

\section{Subgroup analysis}

For the category of overweight and obesity, subgroup analysis showed a basically consistent result with the overall analysis (Table 2). The risk of GBC with overweight and obesity was higher in women, in studies which adjusted for smoking, in studies which NOS quality score $\geq 7$ and in the obese population followed up over 12 years and in studies which located in Europe. Higher risk of GBC was also observed in cohort studies.

It is noted that the risk of gallbladder cancer for women were significantly higher than men both in the category of overweight $\left(1.29(1.08-1.55)\left(\mathrm{I}^{2}=16.7\right)\right.$ vs. $0.98(0.90-1.08)$ $\left.\left(I^{2}=0.0\right)\right)$ and obese $\left(1.61(1.33-1.96)\left(I^{2}=32.1\right)\right.$ vs. $1.43(1.19$ 1.71) $\left.\left(\mathrm{I}^{2}=0.0\right)\right)$ when adjusted for sex. Effect differences weren't observed for different BMI assessment method.

For overweight, some evidence of heterogeneity was found in studies of which duration of follow-up was more than 12 years $\left(I^{2}=63.5\right)$. No significant heterogeneity in obesity was found.

\section{Dose-response meta-analysis}

Seven studies [17-19, 23-26] were included in the dose-response meta-analysis of BMI and GBC. This meta-analysis showed an increased GBC risk of 1.04 (1.02-1.06) for each $1 \mathrm{~kg} / \mathrm{m}^{2}$ increase in BMI as shown in Figure 4. When adjusted for sex, as shown in Figure

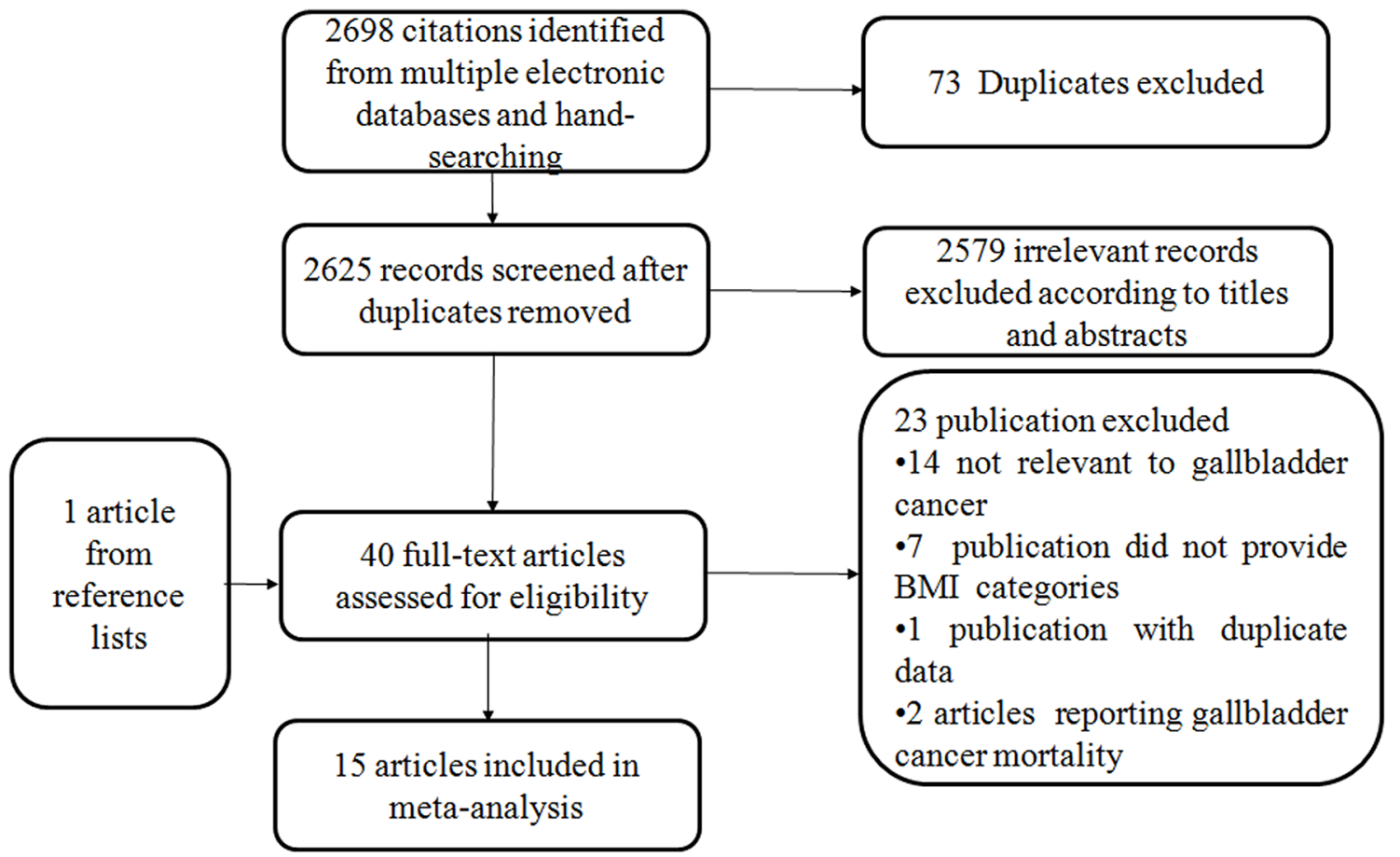

Figure 1: Flowchart of the selection of studies for inclusion in this meta-analysis. 
Table 1: Characteristics of the 15 included articles on BMI and risk of GBC

\begin{tabular}{|c|c|c|c|c|c|c|c|c|c|c|}
\hline \multirow{2}{*}{$\begin{array}{l}\text { Author, year, } \\
\text { country }\end{array}$} & \multirow[t]{2}{*}{ Age ranges } & \multirow{2}{*}{$\begin{array}{c}\text { Duration } \\
\text { of follow- } \\
\text { up }\end{array}$} & \multirow{2}{*}{$\begin{array}{c}\text { Study size } \\
\text { no. }\end{array}$} & \multirow{2}{*}{$\begin{array}{l}\text { No of } \\
\text { cases }\end{array}$} & \multirow{2}{*}{$\begin{array}{c}\text { Assessment } \\
\text { method of } \\
\text { weight/height }\end{array}$} & \multirow{2}{*}{$\begin{array}{c}\text { BMI } \\
\left(\mathrm{kg} / \mathrm{m}^{2}\right)\end{array}$} & \multicolumn{2}{|c|}{ RR(95\%CIs) } & \multirow{2}{*}{$\begin{array}{l}\text { Adjustment } \\
\text { factors }\end{array}$} & \multirow[t]{2}{*}{ NOS } \\
\hline & & & & & & & Men & Women & & \\
\hline \multicolumn{11}{|l|}{ Cohort studies } \\
\hline $\begin{array}{l}\text { Engeland } \\
\text { et al, 2005 } \\
\text { (Norway) }\end{array}$ & $20-74$, range & 23 & $\begin{array}{l}\text { M: } 963619 \\
\text { W:1037892 }\end{array}$ & $\begin{array}{l}\text { M: } 628 \\
W: 1087\end{array}$ & Measured & $\begin{array}{c}18.5-24.9 \\
25.0-29.0 \\
\geq 30.0\end{array}$ & $\begin{array}{l}1.00(\text { Reference }) \\
1.00(0.84-1.17) \\
1.38(1.01-1.89)\end{array}$ & $\begin{array}{l}1.00 \text { (Reference) } \\
1.27(1.10-1.47) \\
1.88(1.60-2.21)\end{array}$ & $\begin{array}{l}\text { Age, birth } \\
\text { cohort }\end{array}$ & 7 \\
\hline $\begin{array}{l}\text { Ishiguro et al, } \\
2008 \text { (Japan) }\end{array}$ & $40-69$, range & 11.78 & $\begin{array}{l}\text { M: } 48681 \\
\text { W: } 53187\end{array}$ & $\begin{array}{l}\mathrm{M}: 30 \\
\mathrm{~W}: 63\end{array}$ & Self-report & $\begin{array}{c}\leq 22.9 \\
23.0-24.9 \\
25.0-26.9 \\
\geq 27.0\end{array}$ & $\begin{array}{l}1.00 \text { (Reference) } \\
0.74(0.28-1.92) \\
1.26(0.48-3.33) \\
1.39(0.45-4.34)\end{array}$ & $\begin{array}{l}1.00(\text { Reference) } \\
0.47(0.22-0.98) \\
0.62(0.29-1.34) \\
0.94(0.48-1.88)\end{array}$ & $\begin{array}{l}\text { Age, gender, } \\
\text { study area, } \\
\text { cholelithiasis, } \\
\text { smoking, } \\
\text { alcohol }\end{array}$ & 6 \\
\hline $\begin{array}{l}\text { Jee et al, } 2008 \\
\text { (Korea) }\end{array}$ & $\begin{array}{l}45.0 \mathrm{M} \\
49.4 \mathrm{~W} \\
\text { average }\end{array}$ & 10.8 & $\begin{array}{l}\text { M: } 770556 \\
\text { W: } 443273\end{array}$ & $\begin{array}{l}\text { M: } 2276 \\
W: 1062\end{array}$ & Measured & $\begin{array}{c}<20.0 \\
20.0-22.9 \\
23.0-24.9 \\
25.0-29.9 \\
\geq 30\end{array}$ & $\begin{array}{l}0.8(0.68-0.94) \\
0.86(0.77-0.96) \\
1.00(\text { Reference }) \\
0.97(0.86-1.1) \\
1.65(1.11-2.44)\end{array}$ & $\begin{array}{l}0.97(0.78-1.21) \\
1.12(0.9-1.41) \\
1.00 \text { (Reference) } \\
1.27(1.02-2.12) \\
1.44(0.98-2.12)\end{array}$ & Age, smoking & 8 \\
\hline $\begin{array}{l}\text { Kuriyama } \\
\text { et al, } 2005 \\
\text { (Japan) }\end{array}$ & $40-70$, range & 9 & $\begin{array}{l}\text { M: } 12485 \\
\text { W: } 15054\end{array}$ & $\begin{array}{l}\text { M: } 9 \\
\text { W: } 24\end{array}$ & Self-report & $\begin{array}{c}18.5-24.9 \\
25.0-27.4 \\
27.5-29.9 \\
\geq 30.0\end{array}$ & $\begin{array}{l}1.00(\text { Reference }) \\
0.46(0.05-3.93)\end{array}$ & $\begin{array}{l}1.00(\text { Reference }) \\
0.83(0.23-2.98) \\
3.43(1.19-9.94) \\
4.45(1.39-14.2)\end{array}$ & $\begin{array}{l}\text { Age, smoking, } \\
\text { type of health } \\
\text { insurance, } \\
\text { intakes of } \\
\text { alcohol, meat, } \\
\text { fish, fruits, } \\
\text { vegetables, } \\
\text { bean paste } \\
\text { soup }\end{array}$ & 7 \\
\hline $\begin{array}{l}\text { Moller } \\
\text { et al, } 1994 \\
\text { (Denmark) }\end{array}$ & $\begin{array}{c}50 \mathrm{M} \\
60 \mathrm{~W}, \\
\text { average }\end{array}$ & 4.8 & $\begin{array}{l}\text { M: } 14531 \\
\text { W: } 29434\end{array}$ & $\begin{array}{c}\text { M: } 2 \\
\text { W: } 26\end{array}$ & $\begin{array}{l}\text { Discharge } \\
\text { diagnosis }\end{array}$ & $\begin{array}{l}\text { Non-obese } \\
\text { Obese }\end{array}$ & $\begin{array}{l}1.00 \text { (Reference) } \\
0.5(0.1-1.8)\end{array}$ & $\begin{array}{l}1.00(\text { Reference }) \\
1.4(0.9-2.1)\end{array}$ & Age & 6 \\
\hline $\begin{array}{l}\text { Oh et al, } 2005 \\
\text { (Korea) }\end{array}$ & $\geq 20$,range & 10 & M: 781283 & M:182 & Measured & $\begin{array}{c}18.5-22.9 \\
23.0-24.9 \\
25.0-26.9 \\
\geq 27.0\end{array}$ & $\begin{array}{l}1.00 \text { (Reference) } \\
1.55(1.1-2.2) \\
1.15(0.74-1.80) \\
1.25(0.70-2.24)\end{array}$ & NA & $\begin{array}{l}\text { Age, area of } \\
\text { residence, } \\
\text { smoking, } \\
\text { exercise, } \\
\text { alcohol }\end{array}$ & 7 \\
\hline $\begin{array}{l}\text { Samanic et al, } \\
2004 \text { (United } \\
\text { States) }\end{array}$ & $\begin{array}{c}52.18 \text { whites } \\
47.63 \text { blacks, } \\
\text { average }\end{array}$ & 12 & $\begin{array}{l}\text { M:3668486 } \\
\text { M: } 832214\end{array}$ & $\begin{array}{l}\text { M: } 291 \\
\text { M: } 47\end{array}$ & $\begin{array}{l}\text { Discharge } \\
\text { diagnosis }\end{array}$ & $\begin{array}{l}\text { White M } \\
\text { Non-obese } \\
\text { Obese } \\
\text { Black M } \\
\text { Non-obese } \\
\text { Obese }\end{array}$ & $\begin{array}{l}\text { White M } \\
1.00 \text { (Reference) } \\
1.70(1.13-2.57) \\
\text { Black M } \\
1.00 \text { (Reference) } \\
0.93(0.23-3.86)\end{array}$ & NA & $\begin{array}{l}\text { Age, calendar } \\
\text { year }\end{array}$ & 6 \\
\hline $\begin{array}{l}\text { Samanic } \\
\text { et al, } 2006 \\
\text { (Sweden) }\end{array}$ & 34.3 , average & 19 & M: 362552 & M: 109 & Measured & $\begin{array}{c}18.5-24.9 \\
25.0-29.0 \\
>30.0\end{array}$ & $\begin{array}{l}1.00(\text { Reference }) \\
0.93(0.62-1.39) \\
1.40(0.73-2.70)\end{array}$ & NA & Age, smoking & 8 \\
\hline $\begin{array}{l}\text { Wolk } \\
\text { et al, } 2001 \\
\text { (Sweden) }\end{array}$ & 24-51, range & 10.3 & $\begin{array}{l}\text { M: } 8165 \\
\text { W: } 19964\end{array}$ & $\begin{array}{c}\text { M: } 2 \\
\text { W: } 29\end{array}$ & $\begin{array}{l}\text { Discharge } \\
\text { diagnosis }\end{array}$ & $\begin{array}{l}\text { Non-obese } \\
\text { Obese }\end{array}$ & $\begin{array}{l}1.00 \text { (Reference) } \\
0.9(0.1-3.4)\end{array}$ & $\begin{array}{l}1.00(\text { Reference }) \\
1.7(1.1-2.5)\end{array}$ & $\begin{array}{l}\text { Age, calendar } \\
\text { year }\end{array}$ & 7 \\
\hline $\begin{array}{l}\text { Song et al, } \\
2008 \text { Korea }\end{array}$ & 40-64, range & 8.75 & W:170481 & W: 88 & Measured & $\begin{array}{c}<18.5 \\
18.5-20.9 \\
21.0-22.9 \\
23.0-24.9 \\
25.0-26.9 \\
27.0-29.9 \\
\geq 30.0\end{array}$ & NA & $\begin{array}{l}2.14(0.71-6.49) \\
1.28(0.59-2.78) \\
1.00(\text { Reference }) \\
1.03(0.52-2.03) \\
1.27(0.65-2.51) \\
1.59(0.79-3.22) \\
1.51(0.5-4.54)\end{array}$ & $\begin{array}{l}\text { Age, height, } \\
\text { smoking } \\
\text { status, alcohol } \\
\text { intake, } \\
\text { physical } \\
\text { exercise, pay } \\
\text { level at study } \\
\text { entry }\end{array}$ & 7 \\
\hline \multicolumn{11}{|l|}{$\begin{array}{l}\text { Case-control } \\
\text { studies }\end{array}$} \\
\hline $\begin{array}{l}\text { Grainge et al, } \\
2009 \text { (UK) }\end{array}$ & 72 , average & & $\begin{array}{l}\text { M and W: } \\
3007\end{array}$ & $\begin{array}{l}\mathrm{M} \text { and } \mathrm{W} \text { : } \\
241\end{array}$ & $\begin{array}{l}\text { Discharge } \\
\text { diagnosis }\end{array}$ & $\begin{array}{c}<24.9 \\
25.0-29.9 \\
\geq 30.0\end{array}$ & $\begin{array}{l}\mathrm{M}+\mathrm{W} \\
1.00 \text { (Reference) } \\
1.03(0.62-1.72) \\
1.51(0.83-1.75)\end{array}$ & NA & $\begin{array}{c}\text { Cigarette } \\
\text { smoking, } \\
\text { alcohol } \\
\text { consumption }\end{array}$ & 8 \\
\hline $\begin{array}{l}\text { Nakadaira } \\
\text { et al, } 2009 \\
\text { (Hungry) }\end{array}$ & $40-69$, range & & W: 37 & $\mathrm{~W}: 41$ & Self-report & $\begin{array}{c}<24.9 \\
25.0-29.9 \\
\geq 30.0\end{array}$ & NA & $\begin{array}{l}1.00(\text { Reference }) \\
1.5(0.4-5.00) \\
0.8(0.3-1.80)\end{array}$ & Age & 7 \\
\hline
\end{tabular}

(Continued) 


\begin{tabular}{|c|c|c|c|c|c|c|c|c|c|c|}
\hline \multirow{2}{*}{$\begin{array}{l}\text { Author, year, } \\
\text { country }\end{array}$} & \multirow[t]{2}{*}{ Age ranges } & \multirow{2}{*}{$\begin{array}{c}\text { Duration } \\
\text { of follow- } \\
\text { up }\end{array}$} & \multirow{2}{*}{$\begin{array}{c}\text { Study size } \\
\text { no. }\end{array}$} & \multirow{2}{*}{$\begin{array}{l}\text { No of } \\
\text { cases }\end{array}$} & \multirow{2}{*}{$\begin{array}{c}\text { Assessment } \\
\text { method of } \\
\text { weight/height }\end{array}$} & \multirow{2}{*}{$\begin{array}{c}\text { BMI } \\
\left(\mathrm{kg} / \mathrm{m}^{2}\right)\end{array}$} & \multicolumn{2}{|c|}{ RR(95\%CIs) } & \multirow{2}{*}{$\begin{array}{l}\text { Adjustment } \\
\text { factors }\end{array}$} & \multirow[t]{2}{*}{ NOS } \\
\hline & & & & & & & Men & Women & & \\
\hline $\begin{array}{l}\text { Strom } \\
\text { et al, } 1995 \\
\text { (Mexico) }\end{array}$ & $45-75$, range & & $\begin{array}{l}\mathrm{M} \text { and } \mathrm{W} \text { : } \\
110\end{array}$ & $\begin{array}{l}M \text { and } W: \\
65\end{array}$ & Self-report & $\begin{array}{c}<24.0 \\
24.0-25.9 \\
26.0-28.0 \\
>28.0\end{array}$ & $\begin{array}{l}\mathrm{M}+\mathrm{W} \\
1.00 \text { (Reference) } \\
1.5(0.5-4.6) \\
2.2(0.7-8.4) \\
1.6(0.4-6.1)\end{array}$ & NA & $\begin{array}{c}\text { Age, } \\
\text { sex,country }\end{array}$ & 6 \\
\hline $\begin{array}{l}\text { Serra et al, } \\
2002 \text { (Chile) }\end{array}$ & $\begin{array}{l}65.8 \mathrm{M} \\
70.6 \mathrm{~W}, \\
\text { average }\end{array}$ & & $\begin{array}{l}\mathrm{M} \text { and } \\
\mathrm{W}: 114\end{array}$ & $\begin{array}{l}M \text { and } W: \\
114\end{array}$ & Self-report & $\begin{array}{c}<25.0 \\
25.0-29.9 \\
\geq 30.0\end{array}$ & $\begin{array}{l}\mathrm{M}+\mathrm{W} \\
1.00(\text { Reference }) \\
0.8(0.4-1.4) \\
0.9(0.4-1.8)\end{array}$ & NA & Age, sex & 7 \\
\hline $\begin{array}{l}\text { Zatonski } \\
\text { et al, } 1997 \\
\text { (Multicenter) }\end{array}$ & $\begin{array}{l}62.7 \mathrm{M} \\
64.2 \mathrm{~W} \\
\text { average }\end{array}$ & & $\begin{array}{l}\text { M: } 798 \\
\text { W: } 681\end{array}$ & $\begin{array}{c}\text { M: } 44 \\
\text { W: } 145\end{array}$ & Self-report & $\begin{array}{l}\text { Quartile 1 } \\
\text { Quartile 2 } \\
\text { Quartile 3 } \\
\text { Quartile 4 }\end{array}$ & $\begin{array}{l}1.0(\text { reference }) \\
1.0(0.3-3.0) \\
0.7(0.3-2.0) \\
1.0(0.3-2.8)\end{array}$ & $\begin{array}{l}1.0 \text { (reference) } \\
1.7(0.9-3.1) \\
1.5(0.8-3.0) \\
2.1(1.2-3.8)\end{array}$ & $\begin{array}{l}\text { Age, center, } \\
\text { alcohol, } \\
\text { smoking, } \\
\text { schooling, } \\
\text { and response } \\
\text { status }\end{array}$ & 7 \\
\hline
\end{tabular}

BMI, body mass index; GBC, gallbladder cancer; RR, relative risk; CI, confidence interval; NA, not available; M, men; W, women; NOS, Newcastle-Ottawa Scale.

$5 \mathrm{a}$, the risk of $\mathrm{GBC}$ for each $1 \mathrm{~kg} / \mathrm{m}^{2}$ increase was more significantly increased in women than men $(6 \%(\mathrm{RR}=1.06$, $95 \% \mathrm{CI}=1.03-1.09)$ vs. $2 \%(\mathrm{RR}=1.02,95 \% \mathrm{CI}=1.00-1.03)$. The dose-response associations were not affected by the adjustment of smoking and follow-up duration (Figure 5).

As shown in Figure 4, a significant nonlinear doseresponse $(\mathrm{P}=0.001)$ relationship between $\mathrm{BMI}$ and risk of $\mathrm{GBC}$ was found. Compared to $\mathrm{BMI}=21.75 \mathrm{~kg} / \mathrm{m}^{2}$, the summary RRs (95\%CIs) of GBC were 1.03(0.96-1.10), $1.41(1.29-1.54)$ for $\mathrm{BMI}=25$ and $30 \mathrm{~kg} / \mathrm{m}^{2}$, respectively. A statistically more significant nonlinear relationship between BMI and GBC risk was observed in women when adjusted by sex (Figure 5). At the point of BMI=25 $\mathrm{kg} / \mathrm{m}^{2}$, the RRs (95\% CIs) for women and men were $1.13(1.01-1.25)$ and $0.98(0.90-1.07)$ respectively. The corresponding RRs $(95 \% \mathrm{CIs})$ at the point of $\mathrm{BMI}=30 \mathrm{~kg} /$ $\mathrm{m}^{2}$ were $1.56(1.39-1.75)$ vs. $1.24(1.06-1.44)$ (Figure 5).

\section{Sensitivity analysis}

In a sensitivity analysis in which one study at a time was removed and the rest analyzed, the pooled RRs ranged from 1.02 to 1.14 for overweight and from 1.45 to 1.61 for obesity, respectively, which indicated that the pooled estimates were stable and not influenced by a single study.

\section{Publication bias}

No evidence for publication bias was indicated by Egger's regression test in the literature on BMI and GBC risk in overweight group $(\mathrm{p}=0.398)$ and dose-response group ( $\mathrm{p}=0.769$ ) (Figure 6a \& Figure 7). For BMI and GBC risk in the obesity group, the Egger's test showed the possibility of publication bias for the analysis $(\mathrm{p}=0.008)$ (Figure 6b). because of this, we undertook the "trim and fill" analysis, and data was unchanged, suggesting that the effect of publication bias could be negligible.

\section{DISCUSSION}

In our meta-analysis, we observed a statistically significant $10 \%$ greater risk of GBC in overweight individuals and a $58 \%$ greater GBC risk in obese individuals when compared with their normal-weight peers. Dose-response meta-analysis showed that each $1 \mathrm{~kg} / \mathrm{m}^{2}$ increase was associated with $4 \%$ greater risk of GBC for overall. When adjusted for sex, at the point of $\mathrm{BMI}=25 \mathrm{~kg} / \mathrm{m}^{2}$, the RRs for women and men were 1.13 and 0.98 respectively. The corresponding RRs at the point of $\mathrm{BMI}=30 \mathrm{~kg} / \mathrm{m}^{2}$ were 1.56 vs. 1.24 .

A meta-analysis by Larsson et al. [32] and Tan et al. [33] examined the association between BMI and risk of gallbladder cancer. They both reported a similar summary for overweight of obese individuals respectively. However, they did not examine the possibility of dose-response relationships between BMI and risk of gallbladder cancer. The World Cancer Research Fund (WCRF) recently updated its review [34] on gallbladder cancer risk factors. Our meta-analysis differs from the review of WCRF in some important aspects. Firstly, we evaluated the risk of gallbladder cancer in overweight individuals and obesity individuals, which indicates the obesity but not the overweight demonstrates a significant association with the risk of gallbladder cancer. This point is not mentioned in the WCRF report. Secondly, the WCRF report included only 8 studies, including 2 studies refereeing relationship of GBC mortality and BMI, which adds heterogeneity to the overall analysis for GBC incidence and BMI. Thirdly, we compared the risk of gallbladder cancer in different data resource in detail, including the study design, duration of follow-up, assessment methods of weight and adjustment factor, which make the result more solid.

Our meta-analysis has several potential limitations that may affect the interpretation of the results. First, 


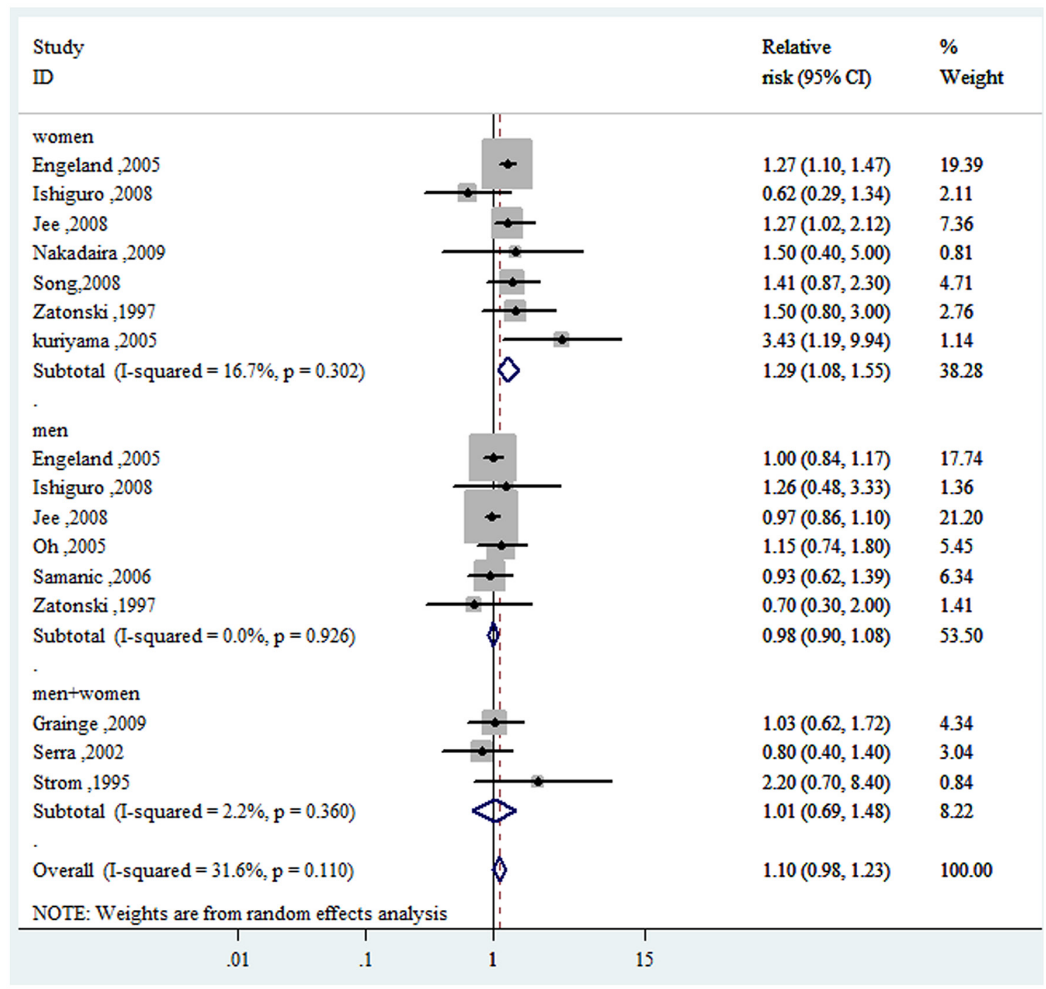

Figure 2: Forest plot of RRs of overweight VS. normal weight for BMI with GBC risk. RR, relative risk; CI, confidence interval; BMI: body mass index; GBC, gallbladder cancer.

\begin{tabular}{|c|c|c|c|}
\hline $\begin{array}{l}\text { Study } \\
\text { ID }\end{array}$ & & $\begin{array}{l}\text { Relative } \\
\text { risk ( } 95 \% \mathrm{CI})\end{array}$ & $\begin{array}{l}\% \\
\text { Weight }\end{array}$ \\
\hline \multicolumn{4}{|l|}{ women } \\
\hline Engeland,2005 & - & $1.88(1.60,2.21)$ & 33.38 \\
\hline Ishiguro,2008 & & $0.94(0.48,1.88)$ & 2.19 \\
\hline Jee,2008 & & $1.44(0.98,2.12)$ & 6.71 \\
\hline Kuriyama,2005 & & $4.45(1.39,14.20)$ & 0.76 \\
\hline Moller,1994 & & $1.40(0.90,2.10)$ & 5.59 \\
\hline Nakadaira,2009 & & $0.80(0.30,1.80)$ & 1.28 \\
\hline Song, 2008 & & $1.51(0.50,4.54)$ & 0.84 \\
\hline Wolk,2001 & & $1.70(1.10,2.50)$ & 5.94 \\
\hline Zatonski, 1997 & & $2.10(1.20,3.80)$ & 3.06 \\
\hline Subtotal (I-squared $=32.1 \%, p=0.161)$ & & $1.61(1.33,1.96)$ & 59.75 \\
\hline \\
\hline & & & \\
\hline \multicolumn{4}{|c|}{$1.38(1.01,1.89)$} \\
\hline Ishiguro, 2008 & & $1.39(0.45,4.34)$ & 0.80 \\
\hline Jee,2008 & & $1.65(1.11,2.44)$ & 6.44 \\
\hline Moller,1994 & & $0.50(0.10,1.80)$ & 0.49 \\
\hline $\mathrm{Oh}, 2005$ & & $1.25(0.70,2.24)$ & 3.00 \\
\hline Samanic,2004(Blacks) & & $0.93(0.23,3.86)$ & 0.52 \\
\hline Samanic, 2004(Whites) & - & $1.70(1.13,2.57)$ & 5.93 \\
\hline Samannic, 2006 & 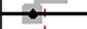 & $1.40(0.73,2.70)$ & 2.38 \\
\hline Wolk,2001 & & $0.90(0.10,3.40)$ & 0.33 \\
\hline Zatonski, 1997 & & $1.00(0.30,2.80)$ & 0.82 \\
\hline Subtotal (I-squared $=0.0 \%, p=0.876$ ) & 0 & $1.43(1.19,1.71)$ & 30.73 \\
\hline . & & & \\
\hline \multicolumn{4}{|l|}{ mentwomen } \\
\hline Grainge,2009 & - & $1.51(0.83,1.75)$ & 7.16 \\
\hline Serrra,2002 & & $0.90(0.40,1.80)$ & 1.81 \\
\hline Strom, 1995 & & $1.60(0.40,6.10)$ & 0.55 \\
\hline Subtotal (I-squared $=0.0 \%, p=0.470$ ) & & $1.38(0.99,1.90)$ & 9.52 \\
\hline Overall (I-squared $=1.9 \%, p=0.434)$ & $\Delta$ & $1.58(1.43,1.75)$ & 100.00 \\
\hline NOTE: Weights are from random effects analysis & 1 & & \\
\hline $\begin{array}{l}1 \\
.1\end{array}$ & & & \\
\hline
\end{tabular}

Figure 3: Forest plot of RRs of obesity VS. normal weight for BMI with GBC risk. RR, relative risk; CI, confidence interval; BMI: body mass index; GBC, gallbladder cancer. 
Table 2: Subgroup analyses of BMI and GBC

\begin{tabular}{|c|c|c|c|c|c|c|}
\hline \multirow[t]{2}{*}{ Study } & \multicolumn{3}{|c|}{ Overweight } & \multicolumn{3}{|c|}{ obesity } \\
\hline & $\begin{array}{l}\text { No. of } \\
\text { studies }\end{array}$ & $\mathrm{RR}(95 \% \mathrm{CI})$ & $I^{2}(\%)$ & $\begin{array}{l}\text { No. of } \\
\text { studies }\end{array}$ & $\mathrm{RR}(95 \% \mathrm{CI})$ & $I^{2}(\%)$ \\
\hline All studies & 12 & $1.10(0.98-1.23)$ & 31.6 & 15 & $1.58(1.43-1.75)$ & 1.9 \\
\hline \multicolumn{7}{|l|}{ Sex } \\
\hline Men & 6 & $0.98(0.90-1.08)$ & 0.0 & 9 & $1.43(1.19-1.71)$ & 0.0 \\
\hline Women & 7 & $1.29(1.08-1.55)$ & 16.7 & 9 & $1.68(1.41-2.00)$ & 32.1 \\
\hline Combined & 3 & $1.01(0.69-1.48)$ & 2.2 & 3 & $1.38(0.99-1.90)$ & 0.0 \\
\hline \multicolumn{7}{|l|}{ Study location } \\
\hline Asia & 5 & $1.14(0.91-1.44)$ & 44.5 & 5 & $1.47(1.18-1.83)$ & 0.0 \\
\hline Europe & 4 & $1.11(0.95-1.28)$ & 31.0 & 6 & $1.55(1.31-1.83)$ & 23.1 \\
\hline \multicolumn{7}{|l|}{ Study design } \\
\hline Cohort & 7 & $1.11(0.96-1.27)$ & 49.3 & 10 & $1.62(1.46-1.80)$ & 0.9 \\
\hline Case-control & 5 & $1.08(0.80-1.46)$ & 0.0 & 5 & $1.40(1.06-1.84)$ & 5.1 \\
\hline \multicolumn{7}{|c|}{$\begin{array}{l}\text { Duration of follow-up(cohort } \\
\text { studies only) }\end{array}$} \\
\hline$\geq 12$ & 2 & $1.09(0.90-1.33)$ & 63.5 & 3 & $1.71(1.49-1.98)$ & 4.1 \\
\hline$<12$ & 5 & $1.14(0.91-1.44)$ & 44.5 & 7 & $1.46(1.23-1.74)$ & 0.0 \\
\hline \multicolumn{7}{|l|}{ NOS quality score } \\
\hline$\geq 7$ & 10 & $1.10(0.98-1.24)$ & 35.3 & 11 & $1.60(1.42-1.80)$ & 8.5 \\
\hline$<7$ & 2 & $1.06(0.52-2.16)$ & 38.7 & 4 & $1.37(1.07-1.76)$ & 0.0 \\
\hline \multicolumn{7}{|c|}{$\begin{array}{l}\text { Assessment method of weight/ } \\
\text { height }\end{array}$} \\
\hline Self-reported & 6 & $1.17(0.79-1.72)$ & 35.0 & 6 & $1.33(0.91-1.95)$ & 31.0 \\
\hline Measured & 5 & $1.10(0.97-1.24)$ & 45.8 & 5 & $1.67(1.48-1.89)$ & 0.0 \\
\hline Discharge diagnosis & 1 & $1.03(0.62-1.72)$ & & 4 & $1.51(1.24-1.84)$ & 0.0 \\
\hline \multicolumn{7}{|l|}{ Adjustment factors } \\
\hline \multicolumn{7}{|l|}{ smoking } \\
\hline Yes & 7 & $1.11(0.94-1.31)$ & 27.7 & 7 & $1.56(1.30-1.86)$ & 0.0 \\
\hline No & 5 & $1.09(0.90-1.32)$ & 36.6 & 8 & $1.47(1.24-1.74)$ & 23.2 \\
\hline \multicolumn{7}{|c|}{ Alcohol consumption } \\
\hline Yes & 6 & $1.18(0.91-1.53)$ & 36.6 & 6 & $1.50(1.17-1.91)$ & 5.1 \\
\hline No & 6 & $1.08(0.95-1.22)$ & 42.4 & 9 & $1.59(1.41-1.78)$ & 5.0 \\
\hline
\end{tabular}

BMI, body mass index; GBC, gallbladder cancer; RR, relative risk; CI, confidence interval.

overweight and obesity are typically associated with unhealthy diets but very few studies adjusted for intake of food; thus, these subgroup analyses are difficult to interpret. Besides, gallstones and increased use of laparoscopic cholecystectomy i.e. increases the risk of gallbladder cancer [15]. Meanwhile, obesity tends to be accompanied with diabetes, which is also associated with increased GBC risk [35]. However, most studies did not adjust for these risk factors. This could have led to an overestimation of the true association between obesity and risk of GBC. Second, weight and height data of several studies in this meta-analysis relied on self-reported and 


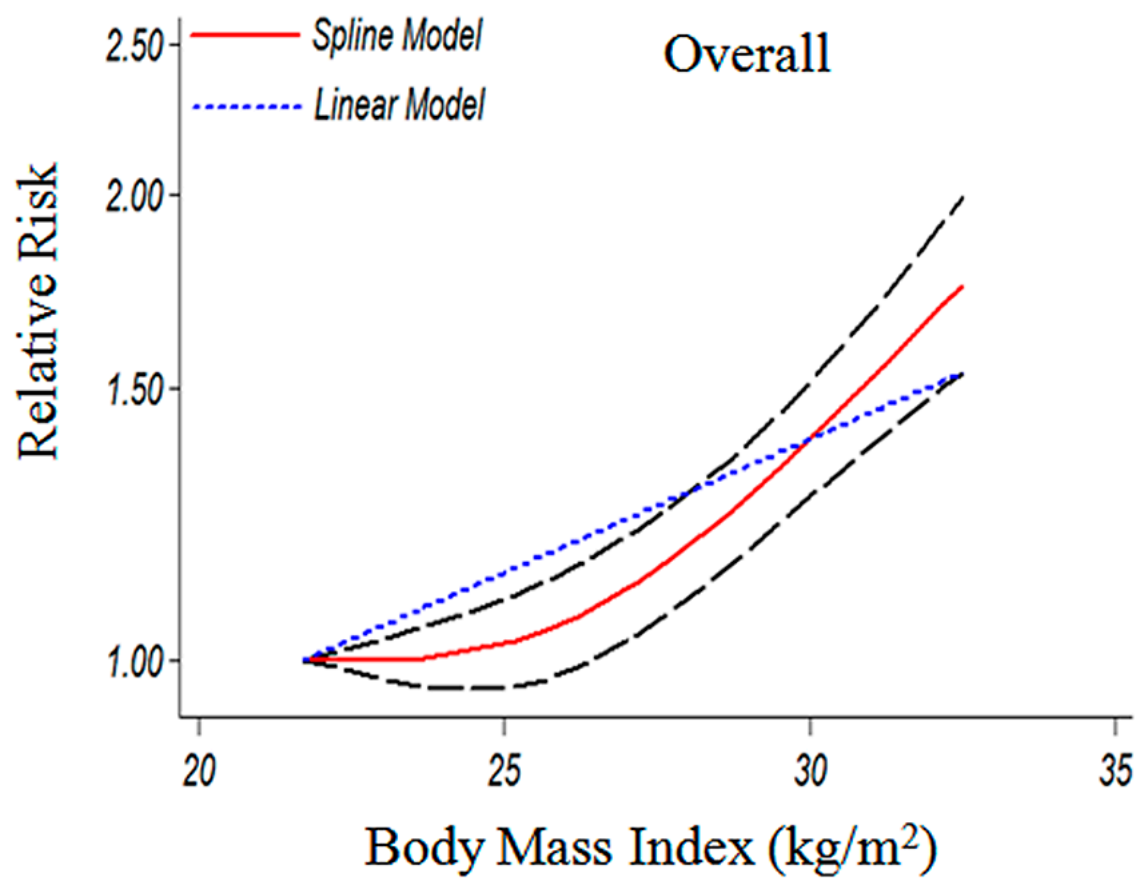

Figure 4: The dose-response analysis between BMI and GBC risk in cohort studies with restricted cubic splines in a multivariate random-effects dose-response model. The solid line and the long dash line represent the estimated RR and its $95 \%$ CI (1.04(1.02-1.06) p=0.001). Short dash line represents the linear relationship (per $1 \mathrm{~kg} / \mathrm{m}^{2}$ increment). RR, relative risk; CI, confidence interval; BMI: body mass index; GBC, gallbladder cancer.
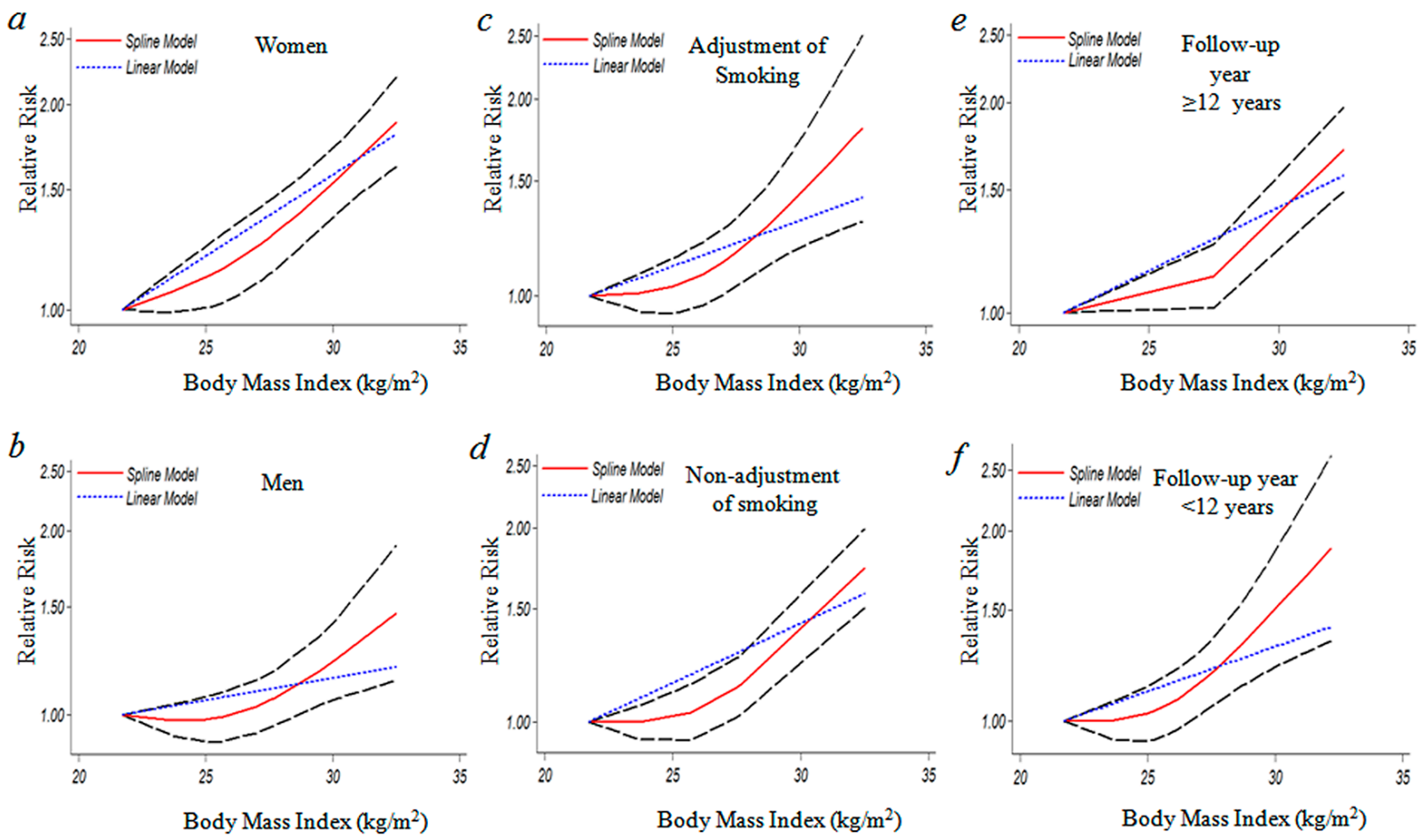

Figure 5: The dose-response analysis between BMI and GBC risk by adjustment of sex, smoking and duration of follow-up. a. women (1.06(1.03-1.09) $\mathrm{p}=0.000)$; b. men (1.02(1.00-1.03) $\mathrm{p}=0.042)$; c. adjustment of smoking (1.04(1.01-1.07) $\mathrm{p}=0.006)$; d. non-adjustment of smoking (1.03(0.99-1.07) $\mathrm{p}=0.113)$; e. follow-up year $\geq 12(1.03(0.99-1.07) \mathrm{p}=0.065)$; f. follow-up year $<12$ years (1.04(1.01-1.07) $\mathrm{p}=0.011)$. The solid line and the long dash line represent the estimated RR and its $95 \%$ CI. Short dash line represents the linear relationship (per $1 \mathrm{~kg} / \mathrm{m}^{2}$ increment).RR, relative risk; CI, confidence interval; BMI: body mass index; GBC, gallbladder cancer. 

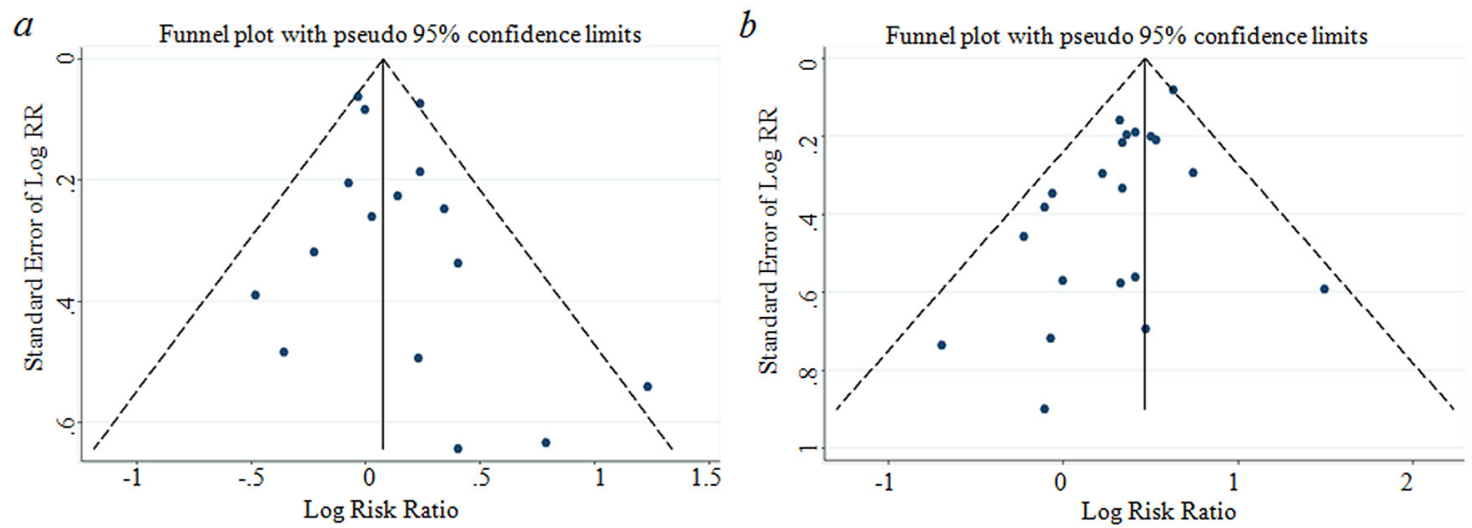

Figure 6: Funnel plot corresponding to the random-effects meta-analysis of the relationship between (a) overweight and GBC risk ( $p=0.398$ by Egger's test); (b) obese and GBC risk( $p=0.008$ by Egger's test). GBC, gallbladder cancer.

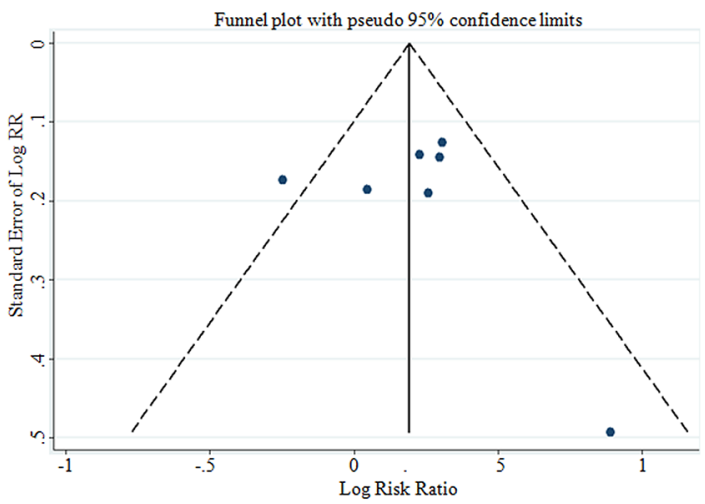

Figure 7: Funnel plot corresponding to the dose-response meta-analysis of the relationship between BMI and GBC risk ( $\mathbf{p}=\mathbf{0 . 7 6 9}$ by Egger's test). GBC, gallbladder cancer.

hospital discharges, which may attenuate the relative risk estimates. However, the RRs for BMI ascertained by measurement were similar to those by self-reported and hospital discharges. Finally, in our meta-analysis including only published studies, it is inevitable that an observed effect might suffer from publication bias because studies with null results tend not to be published. Interestingly, the "trim and fill" analysis showed that publication bias did not appreciably affect our results.

In summary, our meta-analysis indicates that the association of obesity and GBC is stronger in woman than in man. Furthermore, overweight is only associated with GBC in woman. A even stricter weight control might be necessary for woman to prevent GBC.

\section{MATERIALS AND METHODS}

\section{Search strategy}

We systematically searched PUBMED and EMBASE databases to April 17, 2016 for studies on the relationship between $\mathrm{BMI}$ and GBC risk. Our core search consisted of terms related to 'gallbladder cancer, gallbladder neoplasm' combined with 'body mass index, BMI, overweight, or obesity' to identify eligible studies. No language limits were set. In addition, all references listed in the retrieved articles and the reference lists of published meta-analysis $[12,32]$ were also scanned to further identify possible relevant publications.

\section{Study selection}

Studies were eligible for inclusion in the metaanalysis if they satisfied the following criteria: (a) cohort or case-control studies study in which GBC incidence was taken as outcome; (b) having clear description of normal weight, overweight and obesity defined by BMI; (c) the studies reporting risk estimates with the corresponding $95 \%$ confidence intervals $(95 \% \mathrm{CIs})$ or sufficient information to calculate them. When multiple studies had the same or overlapping study populations, only the studies contained the largest sample size or mostly completed were finally included. 


\section{Data extraction}

One investigator (ZML) extracted data, which was checked by another (LSW) and any disagreements were resolved by consensus. The following information was extracted from each of the eligible publications: first author's name, publication year, study location, ethnicity of population, follow-up years, age, measure method of BMI, sample size of gender, BMI categories and risk estimate for each BMI category, and covariates adjusted for multivariable analysis. We assumed that rate ratio and hazard ratio were all valid estimates of the relative risks (RRs), and we, therefore, reported all results as RR for simplicity. We extracted the relative risks with their $95 \%$ CIs that reflected the greatest degree of adjustment for potential confounders.

The midpoint of the upper and lower boundaries of each category was assigned as the mean BMI to each corresponding RRs of every study. If the upper boundary for the highest category (such as $\geq 30$ ) and the lower boundary for the lowest category(such as $<18.5$ ) were not provided in the articles, we assumed that the boundary had the same amplitude as the adjacent category [36]. The method described by D.Aune was used to estimate the distribution of cases or person-years in studies that did not report these but reported the total number of cases and person-years [37].

\section{Statistical analysis}

We used the WHO [38] classification to compare risk estimates for underweight $\left(<18.5 \mathrm{~kg} \mathrm{~m}^{-2}\right)$, overweight (25.0 to $\left.29.9 \mathrm{~kg} \mathrm{~m}^{-2}\right)$ and obesity $\left(\geq 30.0 \mathrm{~kg} \mathrm{~m}^{-2}\right)$ with normal weight (18.5 to $24.9 \mathrm{~kg} \mathrm{~m}^{-2}$ ). Where non-standard categories of BMI were used, we choose the category that was most similar to those defined by the WHO. The relative risks and corresponding standard errors from individual studies were logarithmically transformed to stabilize variances and normalize the distributions. Data were analyzed, and the results were reported, using a random-effects model [39]. To investigate the effect of potential confounders, subgroup analyses were conducted by the available characteristics of studies and participants.

For dose-response analysis, a two-stage randomeffects dose-response meta-analysis [40] was performed to compute the trend from the correlated log RR estimates across levels of BMI, taking into account the betweenstudy heterogeneity. In the first stage, a restricted cubic spline model with three knots at percentiles 10, 50 and $90 \%$ of the distribution was estimated using generalized least-square regression taking into account the correlation within each set of published RRs. Then, the GLST command with the generalized least-squares regression, which required the cases, person-years and mean level of BMI in each category, as well as the BMI level-specific RRs with variance estimated for at least three quantitative categories [41] of each article was used to carry out the dose-response meta-analysis. A p value for nonlinearity was calculated by testing the null hypothesis that the coefficient of the second spline was equal to zero [42].

We assessed heterogeneity between studies with the $\mathrm{I}^{2}$ statistic [43] as a measure of the proportion of total variation in estimates that is due to heterogeneity, where $\mathrm{I}^{2}$ values of $25 \%, 50 \%$, and $75 \%$ correspond to cut-off points for low, moderate, and high degrees of heterogeneity.

Using meta-regression analysis, we further investigated whether the association between BMI and GBC was modified by study-specific factors, including study design and sex. We conducted a sensitivity analysis, in which one study at a time was removed and the rest analyzed to assess whether the results were markedly affected by a single study. Evidence of publication bias was assessed by visual inspection of funnel plots using Egger's regression test [44].

All statistical analyses were performed by Stata 12.0 (Stata Corporation, College Station, TX) and P values of two-sided less than 0.05 were considered statistically significant.

\section{Study quality score}

We assessed the methodological "quality" of included studies based on the Newcastle-Ottawa Scale [45] for quality of case-control studies and cohort studies in meta-analysis; for this assessment, we used the Newcastle-Ottawa Scale star system (range, 0 to 9 stars). In the current study, we considered a study awarded seven or more stars as a high-quality study, because standard validated criteria for important end points have not been established.

\section{ACKNOWLEDGMENTS}

This work is supported by grants from National Natural Science Foundation of China (81472758, 31170783, U1302225).

\section{CONFLICTS OF INTEREST}

No conflict of interest was declared.

\section{REFERENCES}

1. Hundal $\mathrm{R}$ and Shaffer EA. Gallbladder cancer: epidemiology and outcome. Clinical epidemiology. 2014; 6:99-109.

2. Lazcano-Ponce EC, Miquel JF, Munoz N, Herrero R, Ferrecio C, Wistuba, II, Alonso de Ruiz P, Aristi Urista $\mathrm{G}$ and Nervi F. Epidemiology and molecular pathology of gallbladder cancer. CA: a cancer journal for clinicians. 2001; 51:349-364. 
3. Duffy A, Capanu M, Abou-Alfa GK, Huitzil D, Jarnagin W, Fong Y, D'Angelica M, Dematteo RP, Blumgart LH and O'Reilly EM. Gallbladder cancer (GBC): 10-year experience at Memorial Sloan-Kettering Cancer Centre (MSKCC). Journal of surgical oncology. 2008; 98:485-489.

4. Lai CH and Lau WY. Gallbladder cancer-a comprehensive review. The surgeon : journal of the Royal Colleges of Surgeons of Edinburgh and Ireland. 2008; 6:101-110.

5. Randi G, Franceschi S and La Vecchia C. Gallbladder cancer worldwide: geographical distribution and risk factors. Int J Cancer. 2006; 118:1591-1602.

6. Flegal KM, Carroll MD, Kit BK and Ogden CL. Prevalence of obesity and trends in the distribution of body mass index among US adults, 1999-2010. Jama. 2012; 307:491-497.

7. Garcia-Alvarez A, Serra-Majem L, Ribas-Barba L, Castell C, Foz M, Uauy R, Plasencia A and Salleras L. Obesity and overweight trends in Catalonia, Spain (1992-2003): gender and socio-economic determinants. Public health nutrition. 2007; 10:1368-1378.

8. Norberg M, Lindvall K, Stenlund H and Lindahl B. The obesity epidemic slows among the middle-aged population in Sweden while the socioeconomic gap widens. Global health action. 2010; 3:5149-5159.

9. Sperrin M, Marshall AD, Higgins V, Buchan IE and Renehan AG. Slowing down of adult body mass index trend increases in England: a latent class analysis of crosssectional surveys (1992-2010). International journal of obesity. 2014; 38:818-824.

10. Stevens GA, Singh GM, Lu Y, Danaei G, Lin JK, Finucane MM, Bahalim AN, McIntire RK, Gutierrez HR, Cowan M, Paciorek CJ, Farzadfar F, Riley L, Ezzati M and Global Burden of Metabolic Risk Factors of Chronic Diseases Collaborating G. National, regional, and global trends in adult overweight and obesity prevalences. Population health metrics. 2012; 10:22-37.

11. Ng M, Fleming T, Robinson M, Thomson B, Graetz N, Margono C, Mullany EC, Biryukov S, Abbafati C, Abera SF, Abraham JP, Abu-Rmeileh NM, Achoki T, et al. Global, regional, and national prevalence of overweight and obesity in children and adults during 1980-2013: a systematic analysis for the Global Burden of Disease Study 2013. Lancet. 2014; 384:766-781.

12. Renehan AG, Tyson M, Egger M, Heller RF and Zwahlen M. Body-mass index and incidence of cancer: a systematic review and meta-analysis of prospective observational studies. Lancet. 2008; 371:569-578.

13. Perez Perez A, Ybarra Munoz J, Blay Cortes V and de Pablos Velasco P. Obesity and cardiovascular disease. Public health nutrition. 2007; 10:1156-1163.

14. Calle EE, Rodriguez $\mathrm{C}$, Walker-Thurmond $\mathrm{K}$ and Thun MJ. Overweight, obesity, and mortality from cancer in a prospectively studied cohort of U.S. adults. N Engl J Med. 2003; 348:1625-1638.
15. Stinton LM and Shaffer EA. Epidemiology of gallbladder disease: cholelithiasis and cancer. Gut and liver. 2012; 6:172-187.

16. Wolin KY, Carson K and Colditz GA. Obesity and cancer. The oncologist. 2010; 15:556-565.

17. Engeland A, Tretli S, Austad G and Bjorge T. Height and body mass index in relation to colorectal and gallbladder cancer in two million Norwegian men and women. Cancer Causes Control. 2005; 16:987-996.

18. Ishiguro S, Inoue M, Kurahashi N, Iwasaki M, Sasazuki S and Tsugane S. Risk factors of biliary tract cancer in a largescale population-based cohort study in Japan (JPHC study); with special focus on cholelithiasis, body mass index, and their effect modification. Cancer Causes Control. 2008; 19:33-41.

19. Samanic C, Chow WH, Gridley G, Jarvholm B and Fraumeni JF, Jr. Relation of body mass index to cancer risk in 362,552 Swedish men. Cancer Causes Control. 2006; 17:901-909.

20. Samanic C, Gridley G, Chow WH, Lubin J, Hoover RN and Fraumeni JF, Jr. Obesity and cancer risk among white and black United States veterans. Cancer Causes Control. 2004; 15:35-43.

21. Wolk A, Gridley G, Svensson M, Nyren O, McLaughlin JK, Fraumeni JF and Adam HO. A prospective study of obesity and cancer risk (Sweden). Cancer Causes Control. 2001; 12:13-21.

22. Moller H, Mellemgaard A, Lindvig K and Olsen JH. Obesity and cancer risk: a Danish record-linkage study. Eur J Cancer. 1994; 30A:344-350.

23. Jee SH, Yun JE, Park EJ, Cho ER, Park IS, Sull JW, Ohrr H and Samet JM. Body mass index and cancer risk in Korean men and women. Int J Cancer. 2008; 123:1892-1896.

24. Kuriyama S, Tsubono Y, Hozawa A, Shimazu T, Suzuki Y, Koizumi Y, Suzuki Y, Ohmori K, Nishino Y and Tsuji I. Obesity and risk of cancer in Japan. Int J Cancer. 2005; 113:148-157.

25. Oh SW, Yoon YS and Shin SA. Effects of excess weight on cancer incidences depending on cancer sites and histologic findings among men: Korea National Health Insurance Corporation Study. J Clin Oncol. 2005; 23:4742-4754.

26. Song YM, Sung J and Ha M. Obesity and risk of cancer in postmenopausal Korean women. J Clin Oncol. 2008; 26:3395-3402.

27. Nakadaira H, Lang I, Szentirmay Z, Hitre E, Kaster M and Yamamoto M. A case-control study of gallbladder cancer in hungary. Asian Pac J Cancer Prev. 2009; 10:833-836.

28. Grainge MJ, West J, Solaymani-Dodaran M, Aithal GP and Card TR. The antecedents of biliary cancer: a primary care case-control study in the United Kingdom. Br J Cancer. 2009; 100:178-180.

29. Strom BL, Soloway RD, Rios-Dalenz JL, RodriguezMartinez HA, West SL, Kinman JL, Polansky M and Berlin JA. Risk factors for gallbladder cancer. An 
international collaborative case-control study. Cancer. 1995; 76:1747-1756.

30. Serra I, Yamamoto M, Calvo A, Cavada G, Baez S, Endoh $\mathrm{K}$, Watanabe $\mathrm{H}$ and Tajima K. Association of chili pepper consumption, low socioeconomic status and longstanding gallstones with gallbladder cancer in a Chilean population. Int J Cancer. 2002; 102:407-411.

31. Zatonski WA, Lowenfels AB, Boyle P, Maisonneuve P, Bueno de Mesquita HB, Ghadirian P, Jain M, Przewozniak K, Baghurst P, Moerman CJ, Simard A, Howe GR, McMichael AJ, et al. Epidemiologic aspects of gallbladder cancer: a case-control study of the SEARCH Program of the International Agency for Research on Cancer. J Natl Cancer Inst. 1997; 89:1132-1138.

32. Larsson SC and Wolk A. Obesity and the risk of gallbladder cancer: a meta-analysis. Br J Cancer. 2007; 96:1457-1461.

33. Tan W, Gao M, Liu N, Zhang G, Xu T and Cui W. Body Mass Index and Risk of Gallbladder Cancer: Systematic Review and Meta-Analysis of Observational Studies. Nutrients. 2015; 7:8321-8334.

34. World Cancer Research Fund International/American Institute for Cancer Research. Continuous Update Project Report: Diet, Nutrition, Physical Activity and Gallbladder Cancer. 2015. Available at: wcrf.org/ Gallbladder-Cancer-2015.

35. Jamal MM, Yoon EJ, Vega KJ, Hashemzadeh M and Chang KJ. Diabetes mellitus as a risk factor for gastrointestinal cancer among American veterans. World journal of gastroenterology. 2009; 15:5274-5278.

36. Discacciati A, Orsini N and Wolk A. Body mass index and incidence of localized and advanced prostate cancer-a dose-response meta-analysis of prospective studies. Annals of oncology. 2012; 23:1665-1671.
37. Aune D, Greenwood DC, Chan DS, Vieira R, Vieira AR, Navarro Rosenblatt DA, Cade JE, Burley VJ and Norat T. Body mass index, abdominal fatness and pancreatic cancer risk: a systematic review and non-linear dose-response meta-analysis of prospective studies. Ann Oncol. 2012; 23:843-852.

38. Organization WH. Global database on body mass index. WHO.Available at:http:/www.assessmentpsychology.com/ icbmi.htm. [Accessed 25 August 2014]. 2014.

39. DerSimonian R and Laird N. Meta-analysis in clinical trials. Controlled clinical trials. 1986; 7:177-188.

40. Orsini N, Li R, Wolk A, Khudyakov P and Spiegelman D. Meta-analysis for linear and nonlinear dose-response relations: examples, an evaluation of approximations, and software. Am J Epidemiol. 2012; 175:66-73.

41. Orsini N, Bellocco, R. \& Greenland, S. Generalized least squares for trend estimation of summarized dose-response data. The stata journal. 2006; 6:40-47.

42. Desquilbet L and Mariotti F. Dose-response analyses using restricted cubic spline functions in public health research. Stat Med. 2010; 29:1037-1057.

43. Higgins JP and Thompson SG. Quantifying heterogeneity in a meta-analysis. Statistics in medicine. 2002; 21:1539-1558.

44. Egger M, Davey Smith G, Schneider M and Minder C. Bias in meta-analysis detected by a simple, graphical test. Bmj. 1997; 315:629-634.

45. Wu QJ, Yang Y, Vogtmann E, Wang J, Han LH, Li HL and Xiang YB. Cruciferous vegetables intake and the risk of colorectal cancer: a meta-analysis of observational studies. Annals of oncology. 2013; 24:1079-1087. 